\title{
Structured carbon foam derived from waste biomass: application to endocrine disruptor adsorption
}

\author{
Mohamed Zbair ${ }^{1,2} \cdot$ Satu Ojala ${ }^{2}$ (D) $\cdot$ Hamza Khallok $^{3,4} \cdot$ Kaisu Ainassaari $^{2} \cdot$ Zouhair El Assal $^{2} \cdot$ Zineb Hatim $^{3} \cdot$ \\ Riitta L. Keiski ${ }^{2} \cdot$ Mohamed Bensitel $^{1} \cdot$ Rachid Brahmi $^{4}$
}

Received: 23 May 2019 / Accepted: 26 August 2019 / Published online: 19 October 2019

(C) The Author(s) 2019

\begin{abstract}
In this paper, a novel structured carbon foam has been prepared from argan nut shell (ANS) was developed and applied in bisphenol A (BPA) removal from water. The results showed that the prepared carbon foam remove $93 \%$ of BPA ( $60 \mathrm{mg} / \mathrm{L})$. The BPA equilibrium data obeyed the Liu isotherm, displaying a maximum uptake capacity of $323.0 \mathrm{mg} / \mathrm{g}$ at $20^{\circ} \mathrm{C}$. The calculated free enthalpy change $\left(\Delta H^{\circ}=-4.8 \mathrm{~kJ} / \mathrm{mol}\right)$ indicated the existence of physical adsorption between BPA and carbon foam. Avrami kinetic model was able to explain the experimental results. From the regeneration tests, we conclude that the prepared carbon foam has a good potential to be used as an economic and efficient adsorbent for BPA removal from contaminated water. Based on these results and the fact that the developed structured carbon foam is very easy to separate from treated water, it can serve as an interesting material for real water treatment applications.
\end{abstract}

Keywords Endocrine disruptor $\cdot$ Bisphenol A $\cdot$ Adsorption $\cdot$ Carbon foam $\cdot$ Regeneration $\cdot$ Water purification

\section{Introduction}

Endocrine-disrupting substances are chemical compounds or mixtures of compounds that alter endocrine system functions of organisms and, as a result, cause adverse effects on the health of living organisms, their offspring, or part of the population

\section{Highlights}

- Argan nut shells were used as carbon source in the preparation of carbon foam for the first time.

- Carbon foam showed 93\% removal of BPA in the used experimental conditions.

- High adsorption capacity of carbon foam for BPA was achieved.

- The regeneration of the carbon foam was successful after 5 cycles.

Responsible editor: Tito Roberto Cadaval Jr

Electronic supplementary material The online version of this article (https://doi.org/10.1007/s11356-019-06302-8) contains supplementary material, which is available to authorized users.

Satu Ojala

satu.ojala@oulu.fi

1 Laboratory of Catalysis and Corrosion of Materials (LCCM), Department of Chemistry, Faculty of Sciences, University of Chouaïb Doukkali, BP 20, 24000 El Jadida, Morocco
(Vos et al. 2000; López-Ramón et al. 2019). Endocrine disruptors (EDs) can, for example, inhibit or stimulate the secretion of hormones, interfere with the hormone receptor (agonist or antagonist effect), and modify the metabolism of these enzymes (Mills and Chichester 2005). The disturbances are caused after prolonged exposure to these compounds even at low
2 Faculty of Technology, Environmental and Chemical Engineering, University of Oulu, P. O. Box 4300, FI-90014 Oulu, Finland

3 Team of Energy, Materials, and Environment, Department of Chemistry, Faculty of Sciences, University Chouaïb Doukkali, El Jadida, Morocco

4 Laboratory of Coordination and Analytical Chemistry (LCCA), University Chouaïb Doukkali, El Jadida, Morocco 
concentrations. A large number of pollutants have been identified as EDs. These comprise organic compounds such as alkyphenols, chlorinated pesticides, herbicides, and drug compounds (Singleton and Khan 2003). The type of disturbance caused by these compounds is related to the structural similarity between the compound and the hormone.

Despite the existing water treatment, certain pharmaceuticals and EDs end up to the aquatic environment. Numerous endocrine-disrupting substances or metabolites from their biodegradation are found in the effluents and sewage sludge from wastewater treatment plants (Auriol et al. 2006; Tan et al. 2007). Among these endocrine-disrupting substances found, nonylphenol (NP), bisphenol A (BPA), and triclosan (TCS) are the absolute most regularly identified organic xenobiotics in wastewater treatment areas (Kolpin et al. 2002; Boyd et al. 2003, 2004). These substances are distinguished by the existence of a phenolic group in their chemical structure. The $\mathrm{OH}$-group can improve the adsorption of these substances on materials that contain functional surface OH-groups (Zbair et al., 2018a, b, d).

This research focuses on the elimination of a phenolic EDs, bisphenol A (BPA), from aqueous solution. BPA is acutely toxic to the aquatic organisms from 1 to $10 \mathrm{mg} / \mathrm{L}$ concentration range for both fresh water and marine environment (Kang et al. 2006; Aravind et al. 2019). BPA has been detected in several types of water at different concentrations. For example, concentration of $17.2 \mathrm{mg} / \mathrm{L}$ has been observed in in hazardous waste landfill leachate (Yamamoto et al. 2001), 12 $\mu \mathrm{g} / \mathrm{L}$ in stream water (Liu et al. 2009a), and 3.5-59.8 ng/L in drinking water (Santhi et al. 2012). The solubility of BPA in water is $300 \mathrm{mg} / \mathrm{L}$ in normal conditions (Shareef et al. 2006).

Numerous materials such as activated carbons (Asada et al. 2004; Liu et al. 2009b; Zbair et al. 2018a), $\mathrm{CoFe}_{2} \mathrm{O}_{4}$ /activated carbon ( $\mathrm{Li}$ et al. 2014), hybrid material (phenyl-mesoporous silica) (Bhatnagar and Anastopoulos 2017), graphene (Wang et al. 2017), and Fe/AC (Arampatzidou et al. 2018) have been propositioned for removal of BPA. Porous adsorbents are promising materials for adsorption of organic pollutants, because of good physiochemical stability, large specific surface area, and well-developed porosity with high pore volume (Agrawal et al. 2016; Jana et al. 2016; Zbair et al. 2018b). It is known that porous carbon materials are thermally stable, chemically inert, and low-cost and display high adsorption capacity for organic pollutants. The earlier research shows that carbon foam is efficient in the removal of copper, arsenic (V), and lead (Burke et al. 2013; Lee et al. 2015; Agrawal et al. 2016). Therefore, in the current work, we decided to apply carbon foam, prepared from waste biomass (argan nut shell) in BPA removal. The aim was to develop a material that can be easily separated from the treated water and increase surface contact solid/liquid. The chemical composition and surface characteristics of the carbon foam were examined. Batch adsorption experiments were conducted to evaluate the BPA uptake, adsorption mechanism, and possibility to regenerate the carbon foam.

\section{Experimental section}

\section{Preparation of carbon foam}

The argan nut shells (ANS) were collected from the Southwestern Morocco (Taroudant city). First, the raw material was washed with tap water and distilled water. The washed ANS was oven dried at $105{ }^{\circ} \mathrm{C}$ for $12 \mathrm{~h}$. After this, the raw material was ground and sieved to a particle size of $200 \mu \mathrm{m}$. Then the ANS was pyrolyzed at $600^{\circ} \mathrm{C}$ for $2 \mathrm{~h}$ under a nitrogen flow $(100 \mathrm{~mL} / \mathrm{min})$. The employed technique, to produce carbon foam $(\mathrm{CF})$, initially involves the preparation of aqueous slurry from a mixture of pyrolyzed ANS, dispersing agent, structuring agent, and water. Sucrose was used as the both - as the dispersant and the pore promoter (Pradhan and Bhargava 2004). At first, $2.1 \mathrm{~g}$ of sucrose was mixed with $10 \mathrm{~mL}$ of double distilled water for $1 \mathrm{~h}$. Then, $3 \mathrm{~g}$ of pyrolyzed ANS was added step by step to sucrose gel under stirring at $500 \mathrm{rpm}$ until reaching a concentration of $70 \mathrm{wt}-\%$ relative to the pyrolyzed ANS. The resulting slurry was stirred for $24 \mathrm{~h}$ for homogenization. Then, the slurry was poured into a cylindrical silicone mold and dried firstly at $80^{\circ} \mathrm{C}$ for $1 \mathrm{~h}$ and then at $105^{\circ} \mathrm{C}$ for $24 \mathrm{~h}$ to eliminate the surface water and initialize the sucrose consolidation. The molded sample was pyrolyzed under a nitrogen flow of $50 \mathrm{~mL} / \mathrm{min}$ from the room temperature to $900{ }^{\circ} \mathrm{C}$ according to the following cycle: first heating was done with a rate of $0.5^{\circ} \mathrm{C} / \mathrm{min}$ from room temperature to $500{ }^{\circ} \mathrm{C}$ to eliminate sucrose totally (Das 2001). Then the sample was kept at a constant temperature for $1 \mathrm{~h}$ followed by heating with a rate of $5{ }^{\circ} \mathrm{C} / \mathrm{min}$ up to $900{ }^{\circ} \mathrm{C}$, where the temperature was kept constant for $5 \mathrm{~h}$. Finally, cooling was done with the rate of $2{ }^{\circ} \mathrm{C} / \mathrm{min}$ back to the room temperature.

\section{Characterization}

The $\mathrm{N}_{2}$ adsorption-desorption isotherm of carbon foam was examined using a Micromeritics ASAP 2020 instrument (Micrometrics, Norcross, GA, USA) to determine surface area, pore volume, and pore size distribution. The morphological characteristics of carbon foam were analyzed using a field emission scanning electron microscope ZEISS ULTRA PLUS (ZEISS, Oberkochen, Germany) equipped with an energydispersive X-ray spectrometer (EDS) at an accelerating voltage of $15.0 \mathrm{kV}$. The acidity and basicity measurements of carbon foam were done using temperature-programmed desorption (TPD) of $\mathrm{NH}_{3}$ and $\mathrm{CO}_{2}$ with an AutoChem II 2920 (Micromeritics, Norcross, GA, USA) device. Prior to $\mathrm{NH}_{3}-$ TPD analysis, the carbon foam (about $100 \mathrm{mg}$ ) was pretreated with helium $(\mathrm{He})$ at $700{ }^{\circ} \mathrm{C}$ for $30 \mathrm{~min}$. Then, carbon foam was cooled to $100{ }^{\circ} \mathrm{C}$ followed by adsorption of $15 \%$ $\mathrm{NH}_{3}$ in $\mathrm{He}$ (at $100^{\circ} \mathrm{C}$ ) for 60 min and flushing with $\mathrm{He}$ for 30 min, in order to eliminate the physiosorbed $\mathrm{NH}_{3}$. The $\mathrm{NH}_{3}$ desorption was carried out from 100 to $700{ }^{\circ} \mathrm{C}$ including 10 - 
min constant temperature dwell at the final temperature. The flow rate used was $50 \mathrm{~cm}^{3} / \mathrm{min}$ and temperature rise was 10 ${ }^{\circ} \mathrm{C} /$ min during the $\mathrm{NH}_{3}$-TPD analysis. After $\mathrm{NH}_{3}$-TPD analysis, the carbon foam was cooled to room temperature prior $\mathrm{CO}_{2}$-TPD. The sample was pre-treated with $\mathrm{H}_{2}\left(30 \mathrm{~cm}^{3} / \mathrm{min}\right)$ from room temperature to $500{ }^{\circ} \mathrm{C}$ with $10{ }^{\circ} \mathrm{C} / \mathrm{min}$ for $30 \mathrm{~min}$, then cooled to $50{ }^{\circ} \mathrm{C}$ and flushed with Ar with $50 \mathrm{~cm}^{3} / \mathrm{min}$ for $5 \mathrm{~min}$. The adsorption of $5 \% \mathrm{CO}_{2} / \mathrm{Ar}\left(50 \mathrm{~cm}^{3} / \mathrm{min}\right)$ was completed at $50{ }^{\circ} \mathrm{C}$ for 60 min then the physiosorbed $\mathrm{CO}_{2}$ was flushed with Ar $\left(50 \mathrm{~cm}^{3} / \mathrm{min}\right)$ for $60 \mathrm{~min}$. The thermodesorption of $\mathrm{CO}_{2}$ was carried out under Ar flow (50 $\mathrm{cm}^{3} / \mathrm{min}$ ) from 50 to $700{ }^{\circ} \mathrm{C}$, where temperature was left constant during $10 \mathrm{~min}$. The concentrations of desorbed $\mathrm{NH}_{3}$ and $\mathrm{CO}_{2}$ were analyzed by a thermal conductivity detector (TCD) and the total acidity and basicity of carbon foam were determined by integration of the peak area between $100-700{ }^{\circ} \mathrm{C}$ and $40-700^{\circ} \mathrm{C}$, respectively. The PZC (point of zero charge) of carbon foam was determined using the $\mathrm{pH}$ drift method. The carbon foam was mixed with $60 \mathrm{~mL}$ of $0.01 \mathrm{M} \mathrm{NaCl}$ solution. The $\mathrm{pH}$ of the starting solutions (2.0 to 12.0) was adjusted using $\mathrm{HCl}$ and $\mathrm{NaOH}$. After $24 \mathrm{~h}$, the final $\mathrm{pH}$ was measured. The functional surface groups of carbon foam were determined using a Fourier transformed infrared spectroscopy (FTIR-8400S, Shimadzu, Japan).

\section{Batch adsorption experiments}

A stock solution of BPA (100 ppm) was prepared by dissolving the BPA (Alfa Aesar, 97\%) in distillated water. Then, the BPA solutions of desired concentrations were prepared by successive dilutions from their respective stock solution. The effect of solution $\mathrm{pH}$ on BPA $(15 \mathrm{mg} / \mathrm{L})$ removal was examined at various initial $\mathrm{pH}$ values $(2.0-12.0)$ for $2 \mathrm{~h}$, the solutions were adjusted by using $1 \mathrm{M} \mathrm{HCl}$ or $1 \mathrm{M} \mathrm{NaOH}$. The adsorption kinetics was studied using two distinctive starting BPA concentrations, $15.0 \mathrm{mg} / \mathrm{L}$ and $60.0 \mathrm{mg} / \mathrm{L}$. The adsorption isotherm was examined for BPA concentrations of 10 $100 \mathrm{mg} / \mathrm{L}$ at different temperatures $\left(20^{\circ} \mathrm{C}, 30^{\circ} \mathrm{C}\right.$, and $\left.40^{\circ} \mathrm{C}\right)$. After pre-decided times, the samples were taken to assess the remaining BPA concentration in the solution. The BPA concentration was determined using a UV-visible spectrophotometry (SHIMADZU 2450-UV/VIS, JAPAN) at the maximum absorbance wavelength $(274 \mathrm{~nm})$. All batch adsorption experiments of BPA were carried out with a mass of $50 \mathrm{mg}$ of carbon foam in $200 \mathrm{~mL}$ of BPA solution.

\section{Regeneration}

The BPA-laden carbon foam was regenerated using $30 \mathrm{~mL}$ of ethanol (Sigma-Aldrich, 99.8\%). Ethanol and the used carbon foam were stirred at room temperature for $4 \mathrm{~h}$. At that point, the carbon foam was recovered by filtration and dried at 80 ${ }^{\circ} \mathrm{C}$. Adsorption and regeneration cycles were repeated 5 times.

\section{Modeling}

The model parameters of adsorption kinetics and adsorption isotherm were calculated by a non-linear regression method. All equations and models used in this work are presented in Table 1S.

\section{Results and discussion}

\section{Characterization of carbon foam}

The $\mathrm{CO}_{2}$-TPD profiles of carbon foam exhibited the peaks in the temperature ranges of 50-200, 200-460, and upper than $460{ }^{\circ} \mathrm{C}$ that are signifying desorption of $\mathrm{CO}_{2}$ from the weak, medium, and strong basic sites (Cho et al. 2005; El Assal et al. 2018). The carbonaceous materials constructed from biomass have predictably somewhat high amount of hydroxyl groups (-OH), which can adsorb $\mathrm{CO}_{2}$ (Meng et al. 2006). As appeared in Fig. 1 a, the peak between 50 and $200{ }^{\circ} \mathrm{C}$ is linked to the existence of the feeble amount of weak basic sites in carbon foam. Also, the peaks observed between $\sim 200$ and $460{ }^{\circ} \mathrm{C}$ suggest the presence of medium basic sites. The strong basic sites were detected at a temperature above $460{ }^{\circ} \mathrm{C}$. The $\mathrm{NH}_{3}$-TPD profiles of carbon foam are shown in Fig. 1b. Low, medium, and strong acid sites are observed in the temperature ranges of $100-170,170-480$, and $>480{ }^{\circ} \mathrm{C}$, respectively (Arena et al. 1998; El Assal et al. 2017). The maxima of the first and second peak were positioned at 130 and $279{ }^{\circ} \mathrm{C}$. These peaks are analogous to the presence of weak and medium acid sites in carbon foam. Besides, above $480{ }^{\circ} \mathrm{C}$, carbon foam showed only a very small amount of strong acid sites. The quantification showed that carbon foam contains 1.538 $\mathrm{mmol} / \mathrm{g}$ of acid sites and $0.545 \mathrm{mmol} / \mathrm{g}$ of basic sites in total.

To inspect the pore characteristics of the carbon foam, $\mathrm{N}_{2}$ adsorption/desorption isotherms are presented in Fig. 2a. The $\mathrm{N}_{2}$ isotherm of carbon foam is a blend of type I and type IV isotherms, enlightening microporous and mesoporous textural properties. The sharp increment in the adsorption volume at very low relative pressure (Long et al. 2015) demonstrates the presence of micropores in the carbon foam. Besides, the type $\mathrm{H} 2$ hysteresis loop (Rouquerol et al. 1999), which outlines the interconnected networks of pores of diverse sizes and forms, is observed. The carbon foam has a specific surface area $\left(S_{\mathrm{BET}}\right)$ of 435 $\mathrm{m}^{2} / \mathrm{g}$ and a total pore volume of $0.236 \mathrm{~cm}^{3} / \mathrm{g}$. The distribution of pore width based on the Horvath-Kawazoe method indicates that the average pore width is about $0.811 \mathrm{~nm}$ (Fig. 2b).

The SEM images of the carbon foam show a hierarchical pore structure with different shapes and sizes of pores from macropores to micropores (Fig. 3). The observed pores are irregular, and the walls between the larger pores $(\sim 100 \mu \mathrm{m})$ contain smaller pores with around $10-\mu \mathrm{m}$ diameter.The developed porosity of carbon foam can facilitate the adsorption of organic 

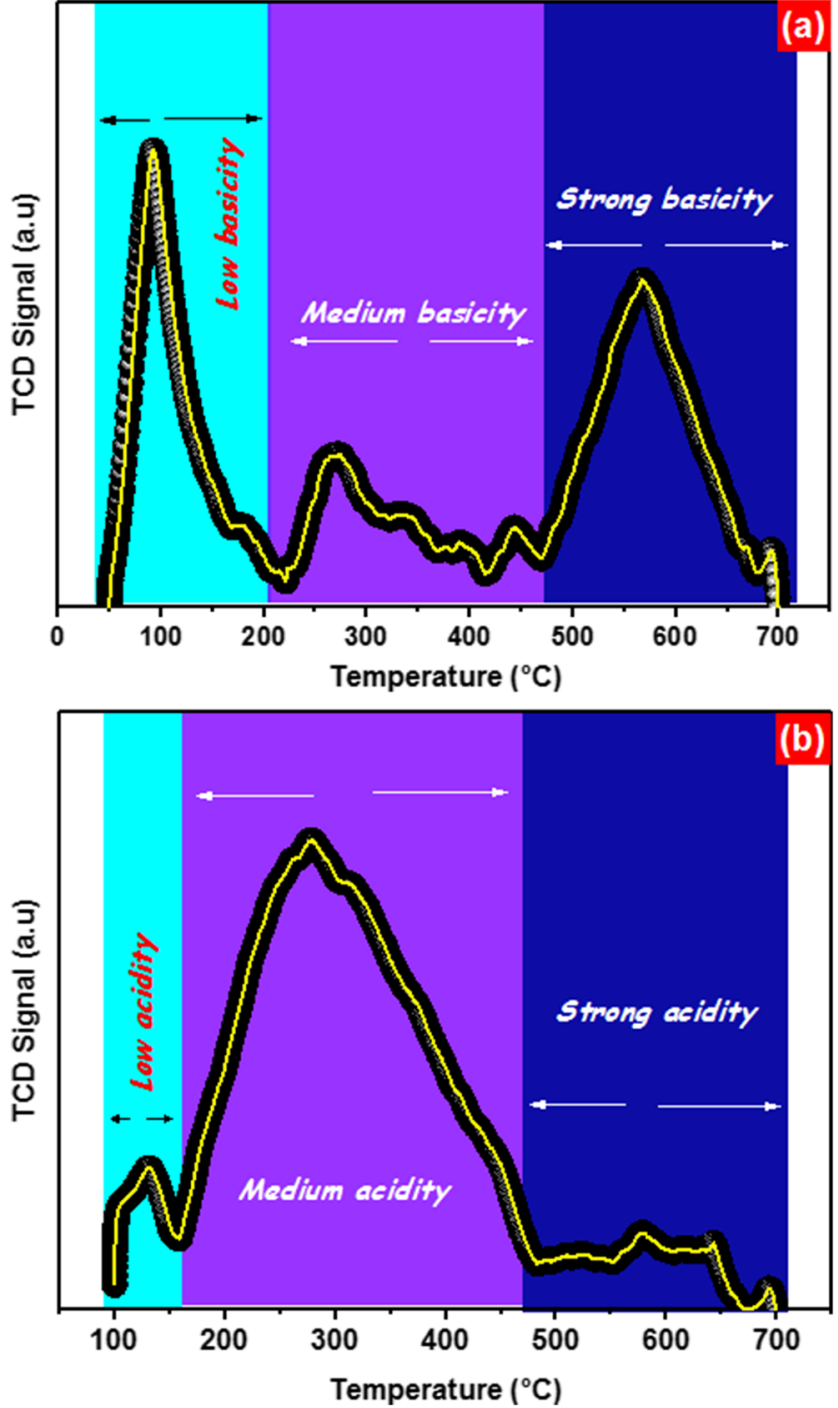

Fig. 1 a Temperature-programmed desorption (TPD) of $\mathrm{CO}_{2}$ and $\mathbf{b}$ temperature-programmed desorption (TPD) of $\mathrm{NH}_{3}$

pollutants due to an increased residence time and turbulence inside the foam. The EDS mappings of the carbon foam (Fig. $1 \mathrm{~S})$ indicate the presence of six main elements: $\mathrm{C}(84.27 \%), \mathrm{O}$ (12.34\%), $\mathrm{Na}(0.48 \%), \mathrm{S}(1.22 \%)$, and $\mathrm{K}(0.48 \%)$.

\section{Adsorption kinetics}

To explain the kinetics of BPA adsorption on the carbon foam, three kinetic models were tested (Fig. 4): the Avrami fractional-order kinetics (AvFO), the pseudo-first-order kinetics $\left(\mathrm{P}-1^{\text {st }}-\mathrm{O}\right)$, and the pseudo-second-order kinetics $\left(\mathrm{P}-2^{\text {nd }}-\mathrm{O}\right)$ (Lima et al. 2015; Tran et al. 2017; Kasperiski et al. 2018). The correctness of the fitting was evaluated by using $R^{2}$ and standard deviation (SD). Higher $R^{2}$ and lower SD values specify the inconsistency between the experimental and the theoretical adsorption capacity (Qcal) values. In this study (Table 1), from the three tested kinetic models, the AvFO
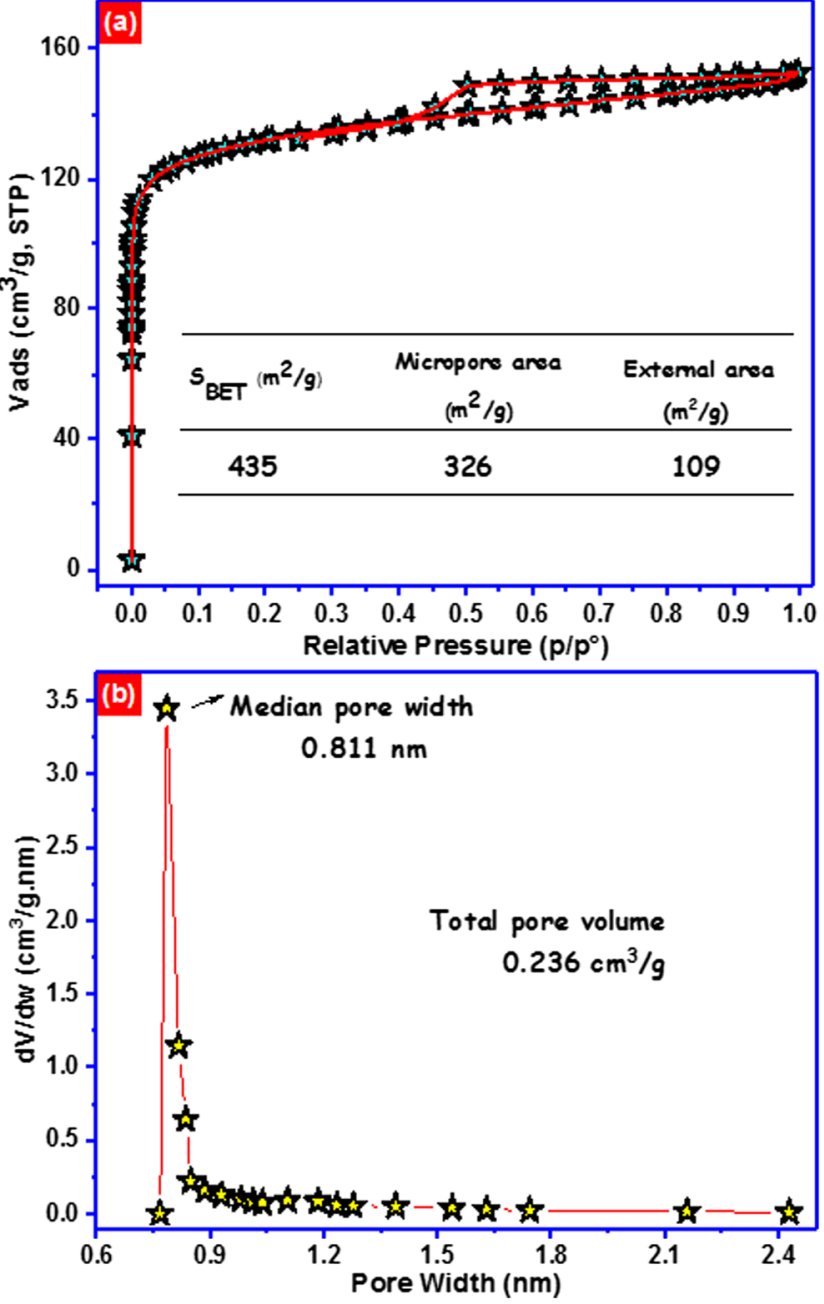

Fig. 2 a $\mathrm{N}_{2}$-sorption isotherm. b Distribution pores width of carbon foam

kinetic model attained the highest $R^{2}$ values of 0.999 for the both used concentrations. It also showed the lowest SD of $0.340 \mathrm{mg} / \mathrm{g}$ and $1.157 \mathrm{mg} / \mathrm{g}$, for $15 \mathrm{mg} / \mathrm{L}$ and $60 \mathrm{mg} / \mathrm{L}$ initial BPA concentration, respectively. This designates that the Qcal estimated by the AvFO kinetic equation is able to explain best the BPA adsorption on the carbon foam. The kinetic rate constant of the models used in this work has different units (Thue et al. 2016), which makes their direct comparison problematic. Hence, the times to reach $50 \%\left(t_{0.5}\right)$ and $95 \%\left(\mathrm{t}_{0.95}\right)$ adsorption of BPA onto the carbon foam at the equilibrium $\left(Q_{\mathrm{e}}\right)$ were interpolated from the fitted kinetic curve according to ref. (Kasperiski et al. 2018). Based on the AvFO kinetic model, the values of $t_{0.5}$ were $2.251 \mathrm{~min}$ and $5.573 \mathrm{~min}$ for the initial BPA concentrations of $15.0 \mathrm{mg} / \mathrm{L}$ and $60.0 \mathrm{mg} / \mathrm{L}$, respectively. The times to reach $95 \%\left(t_{0.95}\right)$ adsorption, $\left(Q_{\mathrm{e}}\right)$ were $9.961 \mathrm{~min}$ and $24.217 \mathrm{~min}$ for $15 \mathrm{mg} / \mathrm{L}$ and $60 \mathrm{mg} / \mathrm{L}$ of BPA initial concentrations, respectively. As a result, the adsorption time for further experiments was fixed at $60 \mathrm{~min}$ in order to guarantee that at higher BPA concentrations maximum adsorption is reached. 
Fig. 3 FESEM image and photo of the carbon foam

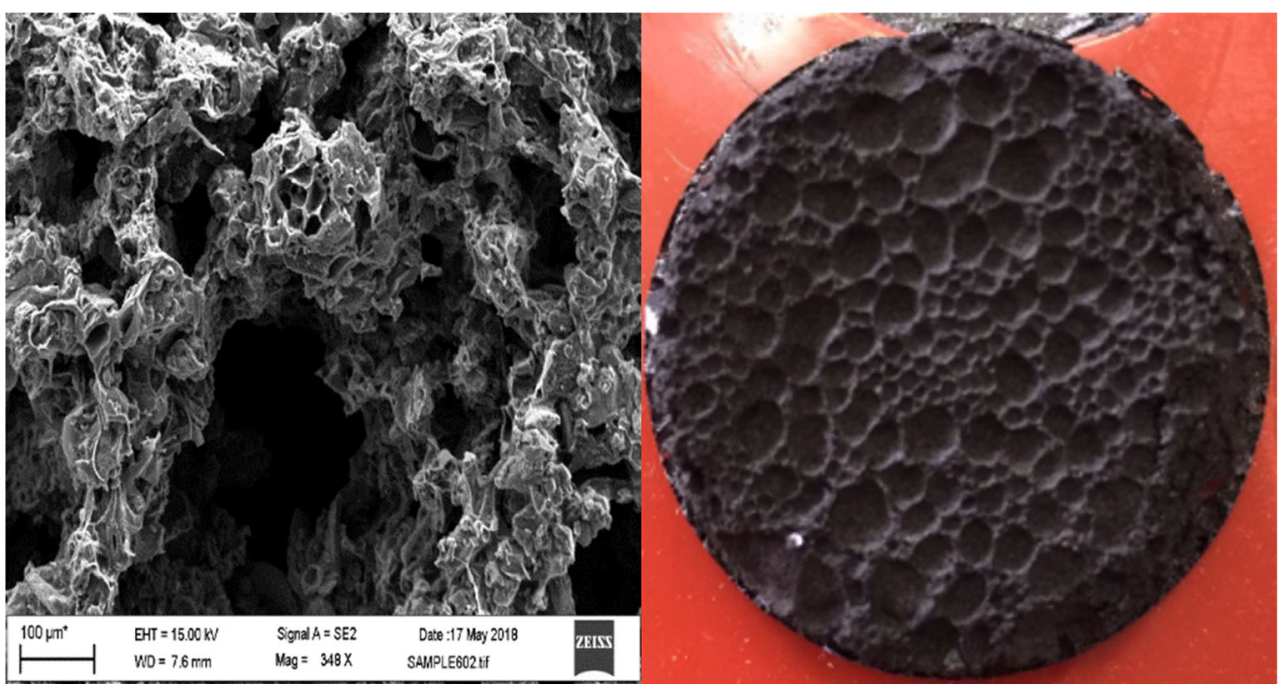

\section{Adsorption isotherms}

The utilization of adsorption isotherms helps to explain the mechanism of adsorption (Lima et al. 2015; Kasperiski et al. 2018). There exists a number of isotherm equations used widely to explain the experimental adsorption data (Lima et al. 2015; Tran et al. 2017). Among the available isotherms, for this study, Langmuir, Freundlich, and Liu's models were selected. Figure 5 presents the adsorption isotherms of BPA on the carbon foam at $20^{\circ} \mathrm{C}, 30^{\circ} \mathrm{C}$, and $40{ }^{\circ} \mathrm{C}$. Based on the $\mathrm{SD}$ and $R^{2}$, the Liu model was the best model to explain BPA adsorption onto the carbon foam (Table 2). The Liu model showed that the SD values varied from 1.117 to 10.639 , and the $R^{2}$ values ranged from 0.970 to 0.999 . In the Liu model, it is assumed that the adsorption sites do not have the same adsorption energy with each other. Earlier, we have shown that the carbon foam has different types of surface functional groups, which is in agreement with the assumption of the Liu model assumption (Dias Lima et al. 2007; Prola et al. 2013).
According to Table 2 and Fig. 5, it is possible to verify that the adsorption capacity of the carbon foam decreases with increasing temperature. The variation of temperature from 20 to $40{ }^{\circ} \mathrm{C}$ weakened the adsorption capacity of the carbon foam. The maximum adsorption $\left(Q_{\mathrm{Li}}\right)$ of the carbon foam for BPA was the following: $323.0 \mathrm{mg} / \mathrm{g}$ at 20 ${ }^{\circ} \mathrm{C}$, less than $287.0 \mathrm{mg} / \mathrm{g}$ at $30{ }^{\circ} \mathrm{C}$ and less than $211.0 \mathrm{mg} /$ $\mathrm{g}$ at $40{ }^{\circ} \mathrm{C}$. Moreover, the values of the Liu equilibrium constant $\left(K_{\mathrm{g}}\right)$ decreased with increasing temperature indicating exothermic adsorption.

In order to compare the uptake capacity of the carbon foam in the removal of the BPA from aqueous solutions, a comparison of BPA adsorption capacities of other adsorbents is presented in Table 3. It can be noted that the carbon foam showed respectable adsorption capacity when compared to the other type of materials. The carbon foam exhibited a high $Q_{\max }$ among the 11 adsorbents inspected, which supports the exceptionally good performance of the carbon foam.
Fig. 4 Adsorption kinetics of BPA onto carbon foam fitted by pseudo-first order $\left(\mathrm{P}-1^{\text {st }}-\mathrm{O}\right)$, pseudo-second order $\left(\mathrm{P}-2^{\text {nd }}-\mathrm{O}\right)$, and Avrami fractional-order (AvFO) kinetic models for $15 \mathrm{mg}$ $\mathrm{L}$ and $60 \mathrm{mg} / \mathrm{L}$ of BPA
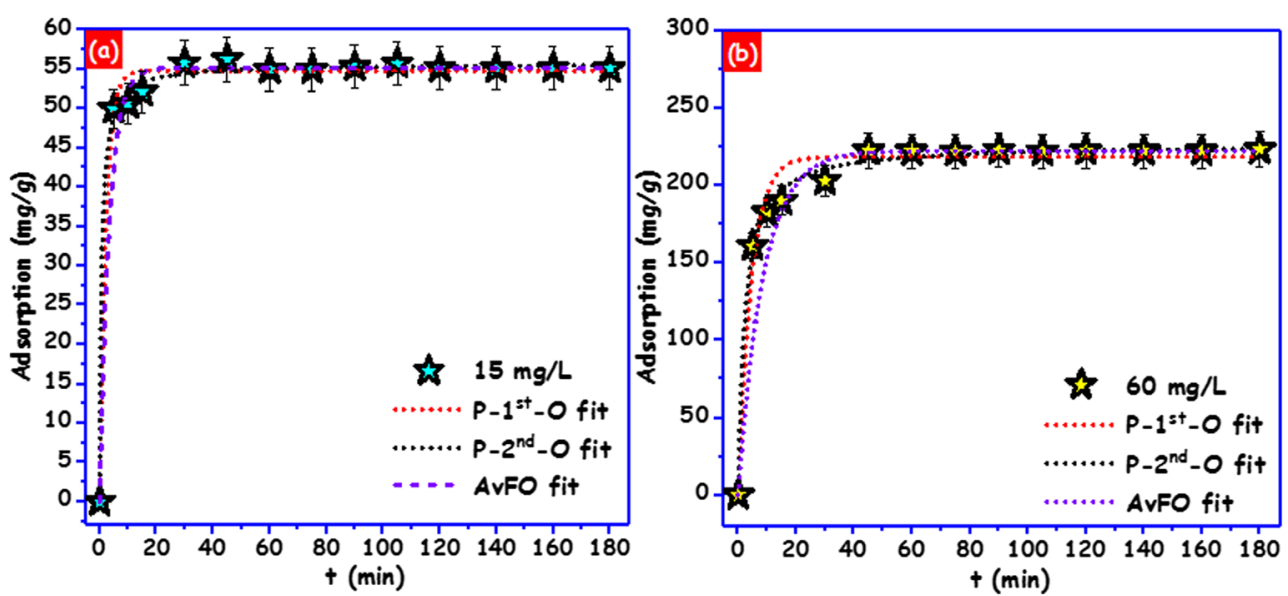
Table 1 Kinetic and equilibrium adsorption parameters

$$
15 \mathrm{mg} / \mathrm{L}
$$

$60 \mathrm{mg} / \mathrm{L}$

Pseudo-first-order

\begin{tabular}{lll}
$Q_{\mathrm{e}}, \mathrm{cal}(\mathrm{mg} / \mathrm{g})$ & 54.77 & 218.49 \\
$K_{1}\left(\mathrm{~min}^{-1}\right)$ & 0.452 & 0.220 \\
$t_{1 / 2}(\mathrm{~min})$ & 1.533 & 3.150 \\
$t_{0.95}(\mathrm{~min})$ & 7.050 & 13.450 \\
$R^{2}$ & 0.990 & 0.972 \\
$\mathrm{SD}(\mathrm{mg} / \mathrm{g})$ & 0.429 & 3.034 \\
Pseudo-second-order & & \\
$Q_{\mathrm{e}}, \mathrm{cal}(\mathrm{mg} / \mathrm{g})$ & 55.63 & 226.66 \\
$K_{2}\left(\mathrm{~g} / \mathrm{mg}^{-1} \mathrm{~min}^{-1}\right)$ & 0.026 & 0.001 \\
$t_{1 / 2}(\mathrm{~min})$ & 0.782 & 2.605 \\
$t_{0.95}(\mathrm{~min})$ & 11.51 & 41.67 \\
$R^{2}$ & 0.996 & 0.995 \\
$\mathrm{SD}(\mathrm{mg} / \mathrm{g})$ & 0.368 & 1.580 \\
$\mathrm{Avrami}-\mathrm{fractional}-\mathrm{order}$ & & \\
$K_{\mathrm{AV}}\left(\mathrm{min}{ }^{-1}\right)$ & 0.281 & 2.111 \\
$Q_{\mathrm{e}}, \mathrm{cal}(\mathrm{mg} / \mathrm{g})$ & 55.11 & 222.36 \\
$n_{\mathrm{AV}}$ & 1.064 & 0.055 \\
$t_{1 / 2}(\mathrm{~min})$ & 2.251 & 5.573 \\
$t_{0.95}(\mathrm{~min})$ & 9.961 & 24.217 \\
$R^{2}$ & 0.999 & 0.999 \\
$\mathrm{SD}(\mathrm{mg} / \mathrm{g})$ & 0.340 & 1.157 \\
\hline & & \\
& &
\end{tabular}

\section{Effect of pH on BPA adsorption}

The solution $\mathrm{pH}$ mostly affects the degree of ionization of BPA and the surface properties (surface charges) of the carbon foam consequently affecting the adsorption of BPA (Zbair et al. 2018a; López-Ramón et al. 2019). In this experiment, the influence of solution $\mathrm{pH}$ in the range of 2.0-12.0 on the uptake of BPA $(15 \mathrm{mg} / \mathrm{L})$ was examined at room temperature. The outcomes demonstrated that when the $\mathrm{pH}$ is $<8.0$ (Fig. $6 a)$, the uptake of BPA was not influenced by the initial $\mathrm{pH}$ of the medium. Figure $6 \mathrm{~b}$ shows that the $\mathrm{pH}_{\mathrm{PZC}}$ of carbon foam is 6.91. At this $\mathrm{pH}$ level of a solution (6.5), the net surface charge of carbon foam is near to zero, and the $\pi-\pi$ dispersion interaction takes place. The $\pi-\pi$ interaction has been applied to describe the adsorption mechanism of the organic molecules such as BPA with benzene rings or $\mathrm{C}=\mathrm{C}$ double bonds adsorbed on the carbonaceous material (Ahsan et al. 2018). In the case of carbon foam, the interaction between the $\pi$ electrons of the benzene rings of BPA and carbon foam occurs through the $\pi-\pi$ electron coupling mechanism. However, when the solution $\mathrm{pH}$ is 8.0 and above, the surface charge of carbon foam is negative and bisphenol A molecules are ionized to their mono- $\left(\mathrm{BPA}^{-}\right)$and divalent $\left(\mathrm{BPA}^{2-}\right)$ anions (Bautista-Toledo et al. 2005). Therefore, the repulsive electrostatic interaction is strengthened. This was the main cause to the low removal efficiency of BPA onto carbon foam at $\mathrm{pH}>$
Fig. 5 Adsorption isotherm of BPA $\left(C_{0} 10-100 \mathrm{mg} / \mathrm{L}\right)$ onto carbon foam at various temperatures $\left(20^{\circ} \mathrm{C}, 30^{\circ} \mathrm{C}\right.$, and $\left.40^{\circ} \mathrm{C}\right)$ and fitted by Langmuir, Freundlich, and Liu models
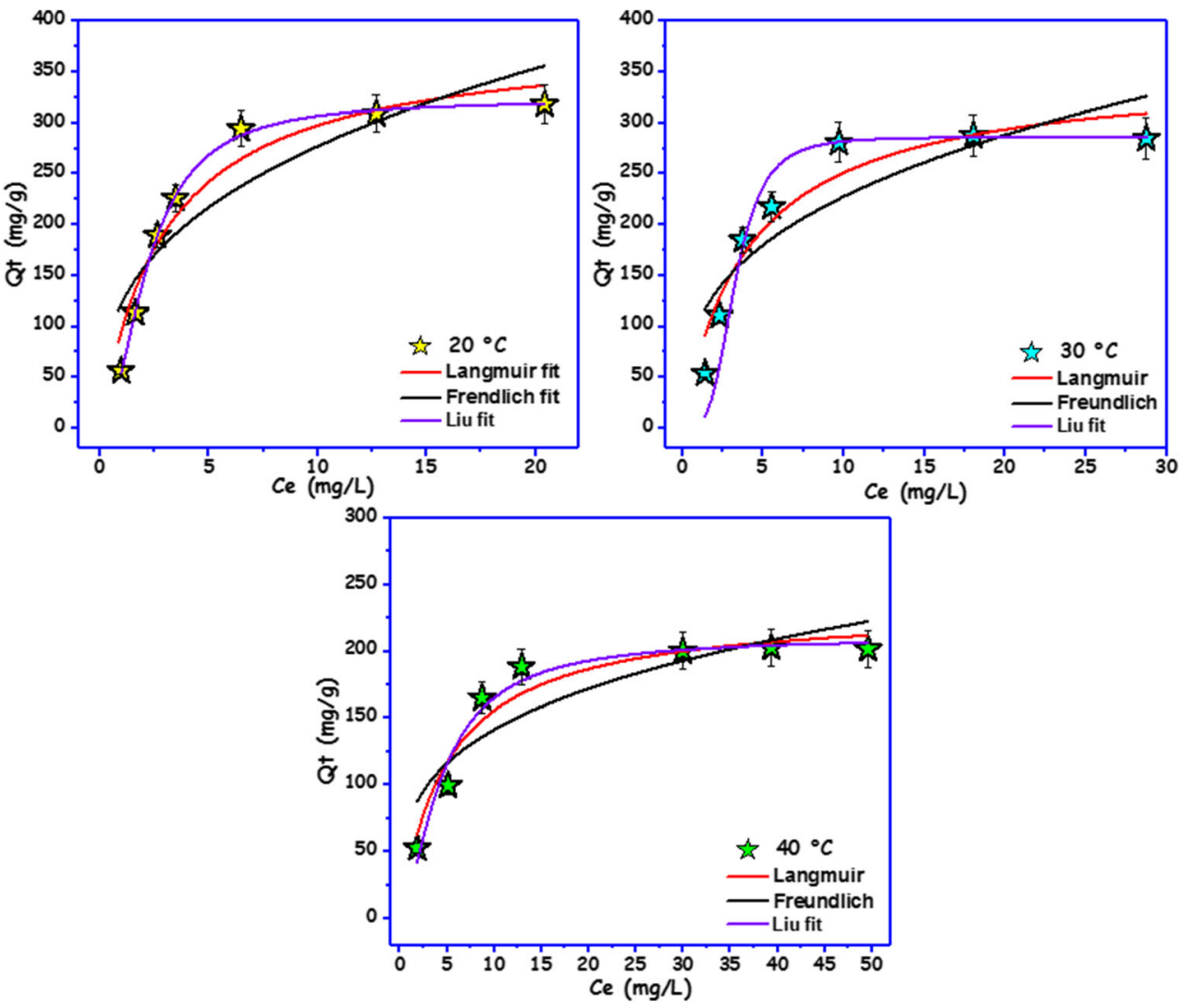
Table 2 Isotherm parameters for the adsorption of BPA onto the carbon foam

\begin{tabular}{llll}
\hline Temperature & $20{ }^{\circ} \mathrm{C}$ & $30{ }^{\circ} \mathrm{C}$ & $40{ }^{\circ} \mathrm{C}$ \\
\hline Langmuir isotherm & & & \\
$Q_{\mathrm{L}}(\mathrm{mg} / \mathrm{g})$ & 386.0 & 353.0 & 223.0 \\
$K_{\mathrm{L}}(\mathrm{L} / \mathrm{mg})$ & 0.339 & 0.246 & 0.201 \\
$R^{2}$ & 0.943 & 0.911 & 0.929 \\
$\mathrm{SD}(\mathrm{mg} / \mathrm{g})$ & 29.280 & 32.515 & 14.433 \\
Freundlich isotherm & & & \\
$K_{\mathrm{F}}(\mathrm{mg} / \mathrm{g})(\mathrm{L} / \mathrm{mg}){ }^{1 / n}$ & 123.0 & 104.0 & 74.0 \\
$n$ & 2.848 & 2.939 & 3.544 \\
$R^{2}$ & 0.792 & 0.740 & 0.761 \\
$\mathrm{SD}(\mathrm{mg} / \mathrm{g})$ & 23.573 & 24.930 & 18.027 \\
$\mathrm{Liu}$ isotherm & & & \\
$Q_{\mathrm{Li}}(\mathrm{mg} / \mathrm{g})$ & 323.0 & 287.0 & 211.0 \\
$\mathrm{~kg}(\mathrm{~L} / \mathrm{mg})$ & 0.455 & 0.304 & 0.226 \\
$n_{\mathrm{L}}$ & 1.950 & 3.708 & 1.567 \\
$R^{2}$ & 0.998 & 0.999 & 0.970 \\
$\mathrm{SD}(\mathrm{mg} / \mathrm{g})$ & 3.558 & 1.117 & 10.639 \\
\hline
\end{tabular}

8.0. These outcomes are consistent with earlier investigations (Tsai et al. 2006a; Soni and Padmaja 2014; Zbair et al. 2018a).

\section{Regeneration}

Regeneration studies are critical to evaluate the recyclability of adsorbents for practical applications owing to important economic and ecological demands for sustainability (Ahsan et al. 2018). Consequently, we decided to wash the used carbon foam with ethanol to regenerate it and to find out information concerning the longer-term use of the carbon foam. The regenerated carbon foam was able to keep almost the same adsorption capacity after the second regeneration and stayed at $91 \%$ after 5 cycles (Fig. 7) indicating that the carbon foam has a decent lifetime.

\section{Proposed adsorption mechanism}

The results of Fourier transformed infrared (FTIR) investigation of the prepared carbon foam are presented in Fig. 8. The broadband at $33971 / \mathrm{cm}$ is related to the stretching vibration mode of the $\mathrm{O}-\mathrm{H}$ groups (Carboxylic groups, phenyl groups, or adsorbed water) on the carbon foam surface (Sajjadi et al. 2018). The stretching frequency at 2922 and $28531 / \mathrm{cm}$ endorses the presence of $\mathrm{CH}_{3}, \mathrm{CH}_{2}$, and $\mathrm{CH}$ groups. The bands positioned at 1736 and $16041 / \mathrm{cm}$ were ascribed to the $\mathrm{C}=\mathrm{O}$ in the carboxyl and lactonic groups and the $\mathrm{C}=\mathrm{C}$ double bond (Zbair et al. 2018a, 2018c). The band at $14081 / \mathrm{cm}$ is associated with the aromatic $\mathrm{C}-\mathrm{C}$ stretching. The peaks located at 1101 and 1023 1/cm were typical of various $\mathrm{C}-\mathrm{O}$ and $\mathrm{O}-\mathrm{C}-\mathrm{O}$ stretching vibrations (Ahmed and Hameed 2018). The existence of $\mathrm{C}-\mathrm{H}$ groups is disclosed with the band at $601 \mathrm{1} / \mathrm{cm}$. This examination demonstrated the capability of carbon foam application as an adsorbent, due to the existence of potential uptake sites (Marques et al. 2018). By comparing the FTIR spectra of the carbon foam before and after BPA adsorption, some surface groups of the carbon foam structure were modified. The FTIR spectrum of the used carbon foam (BPA/ Carbon foam) shows the disappearance of the aliphatic bands at 2922, 2853, and $6011 / \mathrm{cm}$. Moreover, the locations of the $\mathrm{OH}, \mathrm{C}=\mathrm{O}$, and $\mathrm{C}=\mathrm{C}$ groups were shifted from 3397 to 3346 $1 / \mathrm{cm}$, from 1736 to $17801 / \mathrm{cm}$, and from 1604 to $16501 / \mathrm{cm}$, respectively. These changes may signify the hydrogen bonding formed between the $-\mathrm{OH}$ of $\mathrm{BPA}$ and $-\mathrm{OH}$ of the carbon foam. The change of the position of the $\mathrm{C}=\mathrm{O}$ vibration revealed the existence of $\pi-\pi$ interaction: According to
Table 3 Maximum adsorption capacities of BPA by different adsorbents

\begin{tabular}{llll}
\hline Adsorbents & Solid/liquid ratio & $Q_{\max }(\mathrm{mg} / \mathrm{g})$ & References \\
\hline Mesoporous carbon (soft templated) & $0.01 \mathrm{mg} / 100 \mathrm{~mL}$ & 156.0 & (Libbrecht et al. 2015) \\
Graphene & $0.05 \mathrm{~g} / 20 \mathrm{~mL}$ & 94.06 & (Bele et al. 2016) \\
Graphite oxide & $0.05 \mathrm{~g} / 20 \mathrm{~mL}$ & 17.27 & (Bele et al. 2016) \\
Carbon nanotubes (CNTs) & $5 \mathrm{~g} / \mathrm{L}$ & 46.18 & (Li et al. 2015) \\
Montmorillonite modified with DDDMA & $(0.2-0.3 \mathrm{~g}) / 40 \mathrm{~mL}$ & 256.4 & (Park et al. 2014) \\
Hydrophobic zeolite & $0.5 \mathrm{~g} / \mathrm{L}$ & 111.11 & (Tsai et al. 2006a) \\
Coconut-based activated carbon & $0.5 \mathrm{~g} / \mathrm{L}$ & 263.2 & (Tsai et al. 2006b) \\
Graphene & $0.01 \mathrm{~g} / 100 \mathrm{~mL}$ & 181.8 & (Xu et al. 2012) \\
Activated carbon & $20 \mathrm{mg} / 100 \mathrm{~mL}$ & 137 & (Qin et al. 2015) \\
ANS@H2O-120 & $0.01 \mathrm{~g} / 200 \mathrm{~mL}$ & 1408 & (Zbair et al. 2018b) \\
Modified biomass-based carbon & $5 \mathrm{~g} / \mathrm{L}$ & 41.5 & (Juhola et al. 2018) \\
Commercial activated carbon & $0.01 \mathrm{~g} / 100 \mathrm{~mL}$ & 307 & (Libbrecht et al. 2015) \\
Carbon foam & $0.05 \mathrm{~g} / 200 \mathrm{~mL}$ & 323.0 & This work \\
\hline
\end{tabular}



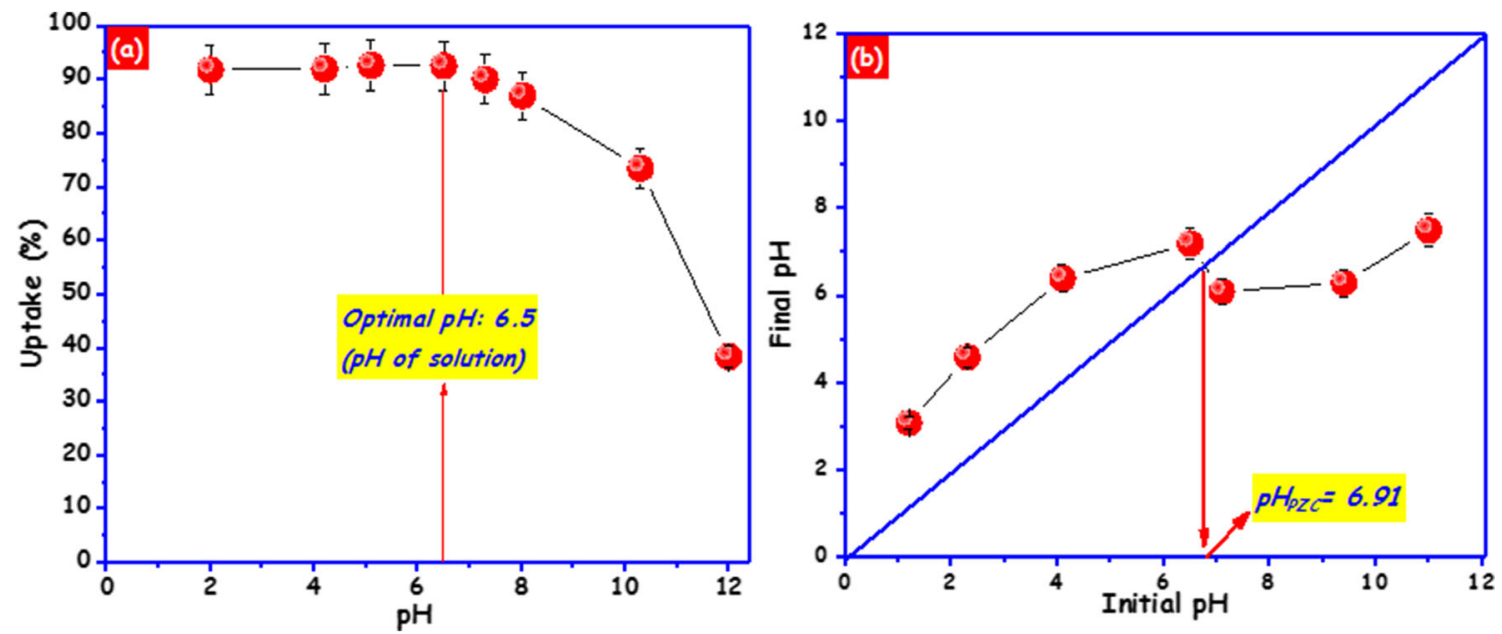

Fig.6 a Effect of $\mathrm{pH}$ on BPA adsorption $\left(C_{0} 15 \mathrm{mg} / \mathrm{L} ; 50 \mathrm{mg}\right.$ of carbon foam; $20^{\circ} \mathrm{C}$; $\left.\mathrm{pH} 2-12 ; 2 \mathrm{~h}\right)$. b Determination of point of zero charge (pH $\mathrm{pzC}$ ) of carbon foam

Mattson et al. (Mattson et al. 1969), in $\pi-\pi$ interaction, the $\mathrm{C}=\mathrm{O}$ on the surface of the carbon foam acts as an electron donor and the aromatic rings of BPA act as electron acceptors. As indicated by the changed position of $\mathrm{C}=\mathrm{O}, \pi-\pi$ interactions also play a role in the adsorption.

\section{Thermodynamic analysis}

To define the thermodynamic information linked to the BPA adsorption onto the carbon foam, Gibbs' free energy change ( $\Delta G^{\circ}, \mathrm{kJ} / \mathrm{mol}$ ), entropy change $\left(\Delta S^{\circ}, \mathrm{J} / \mathrm{mol} \mathrm{K}\right)$, and enthalpy change $\left(\Delta H^{\circ}, \mathrm{kJ} / \mathrm{mol}\right)$ were calculated using equations presented in Table $1 \mathrm{~S}$ and the outcomes were summarized in Table 4 . The negative values of $\Delta G^{\circ}(-281.38 \mathrm{~kJ} / \mathrm{mol}$, -

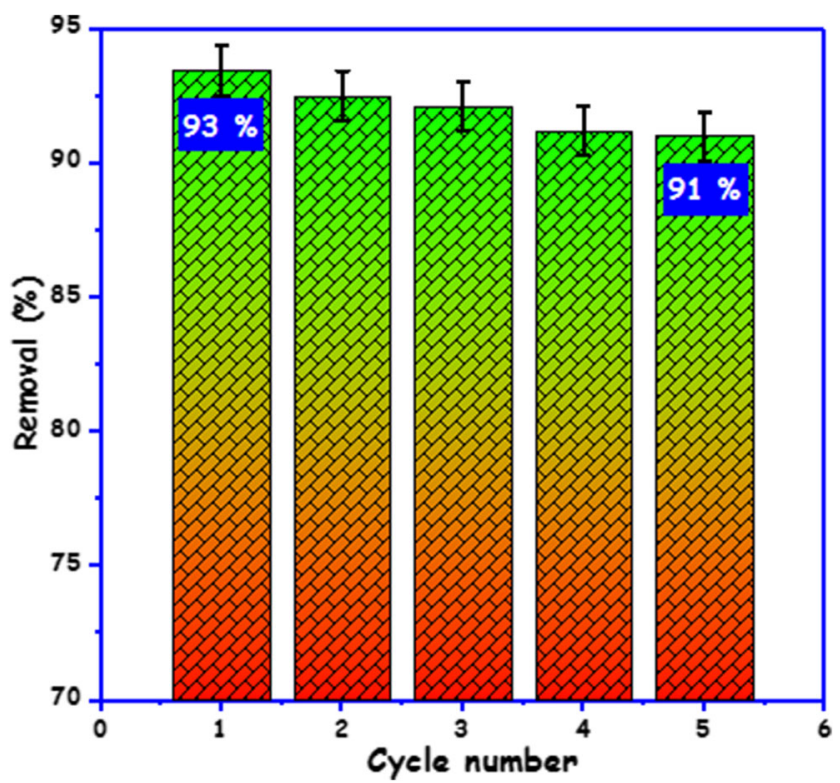

Fig. 7 Regeneration using ethanol and reuse of carbon foam for adsorption of BPA
$28.08 \mathrm{~kJ} / \mathrm{mol}$, and $-28.023 \mathrm{~kJ} / \mathrm{mol}$ ) suggest that the BPA adsorption was a spontaneous and favorable process at all the used temperatures. Likewise, $\Delta S^{\circ}(26.7 \mathrm{~J} / \mathrm{mol} \mathrm{K})$ has a positive value, which shows that the BPA molecules are arbitrarily dispersed on the surface of the carbon foam. The estimation of $\Delta H^{\circ},-4.8 \mathrm{~kJ} / \mathrm{mol}$, was consistent with the physisorption of BPA molecules on the carbon foam (Cardoso et al. 2011). Also, the $\Delta H^{\circ}$ value shows that the BPA adsorption onto the carbon foam was exothermic.

\section{Conclusion}

In this study, the argan nut shell (ANS) was successfully used as a raw material for producing a structured carbon foam. The prepared foam structure presented a well-developed porous structure with different pore sizes and it had a specific surface area of $435 \mathrm{~m}^{2} / \mathrm{g}$. The carbon foam showed $93 \%$ removal of

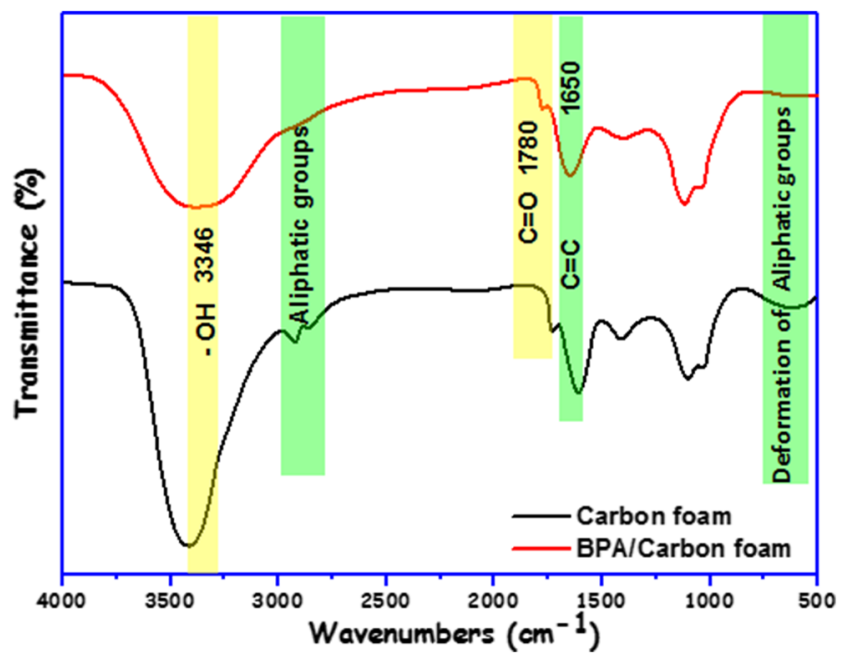

Fig. 8 FTIR spectra before and after adsorption of BPA onto carbon foam 
Table 4 Thermodynamic parameters of the BPA adsorption

\begin{tabular}{|c|c|c|c|c|c|}
\hline \multirow[t]{2}{*}{$\Delta H(\mathrm{~kJ} / \mathrm{mol})$} & \multirow[t]{2}{*}{$\Delta S(\mathrm{~J} / \mathrm{mol} \mathrm{K})$} & & \multicolumn{3}{|c|}{$\Delta G(\mathrm{~kJ} / \mathrm{mol})$} \\
\hline & & $\mathrm{kg}(\mathrm{L} / \mathrm{mol})$ & $\begin{array}{l}-293 \mathrm{~K} \\
103870\end{array}$ & $\begin{array}{l}303 \mathrm{~K} \\
69399\end{array}$ & $\begin{array}{l}313 \mathrm{~K} \\
51592 .\end{array}$ \\
\hline-4.8 & 26.7 & & -281.38 & -28.08 & -28.23 \\
\hline
\end{tabular}

BPA in the used experimental conditions. It was also found that the maximum adsorption capacity of BPA on the carbon foam according to the Liu isotherm $\left(Q_{\text {Liu }}\right)$ was $323.0 \mathrm{mg} / \mathrm{g}$ at $20{ }^{\circ} \mathrm{C}$. Comparison of this value to the values of the other adsorbents demonstrates a high adsorption capacity of the developed carbon foam. The BPA adsorption kinetics on the carbon foam was best explained by the Avrami fractional model. Determination of thermodynamic parameters showed the adsorption to be exothermic and to take place via physisorption. To summarize, the structured carbon foam prepared from the argan nut shell is an excellent material for the BPA removal due to the following: (1) its easy preparation, (2) low price, (3) re-usability,(4) high adsorption capacity, and (4) facile separation from water, which makes it practical for real water purification applications.

Acknowledgements Open access funding provided by University of Oulu including Oulu University Hospital.

Funding information The research leading to these results has received funding from the Erasmus+ Global programme between the University of Oulu, Finland, and the University of Chouaib Doukkali in Morocco. A part of the research was carried out during the NO-WASTE project that received funding from the European Union Seventh Framework Programme (FP / 2007-2013) under the grant agreement no. [PIRSESGA-2012-317714]. The FESEM analysis was carried out at the Center of Microscopy and Nanotechnology, University of Oulu, Finland.

\section{Compliance with ethical standards}

Conflict of interest The authors declare that they have no conflict of interest

Open Access This article is distributed under the terms of the Creative Commons Attribution 4.0 International License (http:// creativecommons.org/licenses/by/4.0/), which permits unrestricted use, distribution, and reproduction in any medium, provided you give appropriate credit to the original author(s) and the source, provide a link to the Creative Commons license, and indicate if changes were made.

\section{References}

Agrawal PR, Kumar R, Uppal H, Singh N, Kumari S, Dhakate SR (2016) Novel 3D lightweight carbon foam as an effective adsorbent for arsenic (v) removal from contaminated water. RSC Adv 6:2989929908. https://doi.org/10.1039/C6RA02208A

Ahmed MJ, Hameed BH (2018) Adsorption behavior of salicylic acid on biochar as derived from the thermal pyrolysis of barley straws. J
Clean Prod 195:1162-1169. https://doi.org/10.1016/j.jclepro.2018. 05.257

Ahsan MA, Islam MT, Hernandez C, Kim H, Lin Y, Curry ML, GardeaTorresdey J, Noveron JC (2018) Adsorptive removal of sulfamethoxazole and bisphenol A from contaminated water using functionalized carbonaceous material derived from tea leaves. J Environ Chem Eng 6:4215-4225. https://doi.org/10.1016/j.jece.2018.06.022

Arampatzidou A, Voutsa D, Deliyanni E (2018) Removal of bisphenol A by Fe-impregnated activated carbons. Environ Sci Pollut Res 25: 25869-25879. https://doi.org/10.1007/s11356-018-2652-4

Aravind P, Devarajan A, Solaiappan A, Selvaraj H, Sundaram M (2019) Removal of BPA from thermal cash receipts via electro oxidation cum biodegradation: evaluating its degradation mechanism and in silico toxicity analysis. J Water Process Eng 31:100849. https://doi. org/10.1016/j.jwpe.2019.100849

Arena F, Dario R, Parmaliana A (1998) A characterization study of the surface acidity of solid catalysts by temperature programmed methods. Appl Catal A Gen 170:127-137. https://doi.org/10.1016/ S0926-860X(98)00041-6

Asada T, Oikawa K, Kawata K, Ishihara S, Iyobe T, Yamada A (2004) Study of removal effect of bisphenol a and $\beta$-estradiol by porous carbon. J Heal Sci 50:588-593. https://doi.org/10.1248/jhs.50.588

Auriol M, Filali-Meknassi Y, Tyagi RD, Adams CD, Surampalli RY (2006) Endocrine disrupting compounds removal from wastewater, a new challenge. Process Biochem 41:525-539. https://doi.org/10. 1016/j.procbio.2005.09.017

Bautista-Toledo I, Ferro-García MA, Rivera-Utrilla J, Moreno-Castilla C, Vegas Fernández FJ (2005) Bisphenol A removal from water by activated carbon. Effects of carbon characteristics and solution chemistry. Environ Sci Technol 39:6246-6250. https://doi.org/10. 1021/es0481169

Bele S, Samanidou V, Deliyanni E (2016) Effect of the reduction degree of graphene oxide on the adsorption of Bisphenol A. Chem Eng Res Des 109:573-585. https://doi.org/10.1016/j.cherd.2016.03.002

Bhatnagar A, Anastopoulos I (2017) Adsorptive removal of bisphenol A (BPA) from aqueous solution: a review. Chemosphere 168:885902. https://doi.org/10.1016/j.chemosphere.2016.10.121

Boyd GR, Reemtsma H, Grimm DA, Mitra S (2003) Pharmaceuticals and personal care products (PPCPs) in surface and treated waters of Louisiana, USA and Ontario, Canada. Sci Total Environ 311:135149. https://doi.org/10.1016/S0048-9697(03)00138-4

Boyd GR, Palmeri JM, Zhang S, Grimm DA (2004) Pharmaceuticals and personal care products (PPCPs) and endocrine disrupting chemicals (EDCs) in stormwater canals and Bayou St. John in New Orleans, Louisiana, USA. Sci Total Environ 333:137-148. https://doi.org/10. 1016/j.scitotenv.2004.03.018

Burke DM, Morris MA, Holmes JD (2013) Chemical oxidation of mesoporous carbon foams for lead ion adsorption. Sep Purif Technol 104: 150-159. https://doi.org/10.1016/j.seppur.2012.10.049

Cardoso NF, Pinto RB, Lima EC, Calvete T, Amavisca CV, Royer B, Cunha ML, Fernandes THM, Pinto IS (2011) Removal of remazol black B textile dye from aqueous solution by adsorption. Desalination 269:92-103. https://doi.org/10.1016/j.desal.2010.10. 047

Cho SH, Park JS, Choi SH, Lee SK, Kim SH (2005) Effect of water vapor on carbon monoxide oxidation over promoted platinum catalysts. Catal Lett 103:257-261. https://doi.org/10.1007/s10562-005-71626

Das RN (2001) Nanocrystalline ceramics from sucrose process. Mater Lett 47:344-350. https://doi.org/10.1016/S0167-577X(00)00264-0

Dias Lima M, Jung de Andrade M, Locatteli A, Balzaretti N, Nobre F, Perez Bergmann C, Roth S (2007) The effect of the combustible agents on the synthesis of $\mathrm{Fe}-\mathrm{Mo} / \mathrm{MgO}$ catalysts for the production of carbon nanotubes. Phys Status Solidi 244:3901-3906. https://doi. org/10.1002/pssb.200776115 
El Assal Z, Ojala S, Pitkäaho S et al (2017) Comparative study on the support properties in the total oxidation of dichloromethane over $\mathrm{Pt}$ catalysts. Chem Eng J 313:1010-1022. https://doi.org/10.1016/j.cej. 2016.10.139

El Assal Z, Ojala S, Drif A, Zbair M, Bensitel M, Laurence Pirault R, Tuomas N, Satu P, Keiski L, Brahmi R (2018) Total oxidation of dichloromethane over silica modified alumina catalysts washcoated on ceramic monoliths. Catalysts 8:339. https://doi.org/10.3390/ catal 8080339

Jana P, Palomo del Barrio E, Fierro V, Medjahdi G, Celzard A (2016) Design of carbon foams for seasonal solar thermal energy storage. Carbon N Y 109:771-786. https://doi.org/10.1016/j.carbon.2016. 08.048

Juhola R, Runtti H, Kangas T, Hu T, Romar H, Tuomikoski S (2018) Bisphenol A removal from water by biomass-based carbon: isotherms, kinetics and thermodynamics studies. Environ Technol:110. https://doi.org/10.1080/09593330.2018.1515990

Kang J-H, Kondo F, Katayama Y (2006) Human exposure to bisphenol A. Toxicology 226:79-89. https://doi.org/10.1016/j.tox.2006.06. 009

Kasperiski FM, Lima EC, Umpierres CS, dos Reis GS, Thue PS, Lima DR, Dias SLP, Saucier C, da Costa JB (2018) Production of porous activated carbons from Caesalpinia ferrea seed pod wastes: highly efficient removal of captopril from aqueous solutions. J Clean Prod 197:919-929. https://doi.org/10.1016/j.jclepro.2018.06.146

Kolpin DW, Furlong ET, Meyer MT, Thurman EM, Zaugg SD, Barber LB, Buxton HT (2002) Pharmaceuticals, hormones, and other organic wastewater contaminants in U.S. streams, 1999-2000: A National Reconnaissance. Environ Sci Technol 36:1202-1211. https://doi.org/10.1021/es011055j

Lee C-G, Jeon J-W, Hwang M-J, Ahn KH, Park C, Choi JW, Lee SH (2015) Lead and copper removal from aqueous solutions using carbon foam derived from phenol resin. Chemosphere 130:59-65. https://doi.org/10.1016/j.chemosphere.2015.02.055

Li Z, Gondal MA, Yamani ZH (2014) Preparation of magnetic separable $\mathrm{CoFe} 2 \mathrm{O} 4 / \mathrm{PAC}$ composite and the adsorption of bisphenol A from aqueous solution. J Saudi Chem Soc 18:208-213. https://doi.org/10. 1016/j.jscs.2011.06.012

Li S, Gong Y, Yang Y, He C, Hu L, Zhu L, Sun L, Shu D (2015) Recyclable CNTs/Fe3O4 magnetic nanocomposites as adsorbents to remove bisphenol A from water and their regeneration. Chem Eng J 260:231-239. https://doi.org/10.1016/j.cej.2014.09.032

Libbrecht W, Vandaele K, De Buysser K et al (2015) Tuning the pore geometry of ordered mesoporous carbons for enhanced adsorption of bisphenol-A. Materials (Basel). 8:1652-1665

Lima ÉC, Adebayo MA, Machado FM (2015) Kinetic and equilibrium models of adsorption. In: Bergmann CP, Machado FM (eds) Carbon Nanomaterials as adsorbents for environmental and biological applications. Springer International Publishing, Cham, pp 33-69

Liu G, Ma J, Li X, Qin Q (2009a) Adsorption of bisphenol A from aqueous solution onto activated carbons with different modification treatments. J Hazard Mater 164:1275-1280. https://doi.org/10.1016/ j.jhazmat.2008.09.038

Liu G, Ma J, Li X, Qin Q (2009b) Adsorption of bisphenol A from aqueous solution onto activated carbons with different modification treatments. J Hazard Mater 164:1275-1280. https://doi.org/10.1016/ j.jhazmat.2008.09.038

Long C, Chen X, Jiang L, Zhi L, Fan Z (2015) Porous layer-stacking carbon derived from in-built template in biomass for high volumetric performance supercapacitors. Nano Energy 12:141-151. https:// doi.org/10.1016/j.nanoen.2014.12.014

López-Ramón MV, Ocampo-Pérez R, Bautista-Toledo MI, Rivera-Utrilla J, Moreno-Castilla C, Sánchez-Polo M (2019) Removal of bisphenols $\mathrm{A}$ and $\mathrm{S}$ by adsorption on activated carbon clothes enhanced by the presence of bacteria. Sci Total Environ 669:767-776. https://doi.org/10.1016/j.scitotenv.2019.03.125
Marques BS, Frantz TS, Sant'Anna Cadaval Junior TR, de Almeida Pinto LA, Dotto GL (2018) Adsorption of a textile dye onto piaçava fibers: kinetic, equilibrium, thermodynamics, and application in simulated effluents. Environ Sci Pollut Res. https://doi.org/10.1007/ s11356-018-3587-5

Mattson JA, Mark HB, Malbin MD et al (1969) Surface chemistry of active carbon: specific adsorption of phenols. J Colloid Interface Sci 31:116-130. https://doi.org/10.1016/0021-9797(69)90089-7

Meng Y, Gu D, Zhang F, Shi Y, Cheng L, Feng D, Wu Z, Chen Z, Wan Y, Stein A, Zhao D (2006) A Family of highly ordered mesoporous polymer resin and carbon structures from organic-organic self-assembly. Chem Mater 18:4447-4464. https://doi.org/10.1021/ $\mathrm{cm} 060921 \mathrm{u}$

Mills LJ, Chichester C (2005) Review of evidence: are endocrinedisrupting chemicals in the aquatic environment impacting fish populations? Sci Total Environ 343:1-34. https://doi.org/10.1016/j. scitotenv.2004.12.070

Park Y, Sun Z, Ayoko GA, Frost RL (2014) Bisphenol A sorption by organo-montmorillonite: Implications for the removal of organic contaminants from water. Chemosphere 107:249-256. https://doi. org/10.1016/j.chemosphere.2013.12.050

Pradhan M, Bhargava P (2004) Effect of Sucrose on fabrication of ceramic foams from aqueous slurries. J Am Ceram Soc 88:216-218. https://doi.org/10.1111/j.1551-2916.2004.00001.x

Prola LDT, Acayanka E, Lima EC, Umpierres CS, Vaghetti JCP, Santos WO, Laminsi S, Djifon PT (2013) Comparison of Jatropha curcas shells in natural form and treated by non-thermal plasma as biosorbents for removal of Reactive Red 120 textile dye from aqueous solution. Ind Crops Prod 46:328-340. https://doi.org/10.1016/j. indcrop.2013.02.018

Qin F-X, Jia S-Y, Liu Y, Li HY, Wu SH (2015) Adsorptive removal of bisphenol A from aqueous solution using metal-organic frameworks. Desalin Water Treat 54:93-102. https://doi.org/10.1080/ 19443994.2014.883331

Rouquerol F, Rouquerol J, Sing K (1999) CHAPTER 9 - Adsorption by active carbons. Academic Press, London 237-285. https://doi.org/ 10.1016/B978-012598920-6/50010-5

Sajjadi S-A, Mohammadzadeh A, Tran HN, Anastopoulos I, Dotto GL, Lopičić ZR, Sivamani S, Rahmani-Sani A, Ivanets A, HosseiniBandegharaei A (2018) Efficient mercury removal from wastewater by pistachio wood wastes-derived activated carbon prepared by chemical activation using a novel activating agent. J Environ Manage 223:1001-1009. https://doi.org/10.1016/j.jenvman.2018. 06.077

Santhi VA, Sakai N, Ahmad ED, Mustafa AM (2012) Occurrence of bisphenol A in surface water, drinking water and plasma from Malaysia with exposure assessment from consumption of drinking water. Sci Total Environ 427-428:332-338. https://doi.org/10.1016/ j.scitotenv.2012.04.041

Shareef A, Angove MJ, Wells JD, Johnson BB (2006) Aqueous solubilities of estrone, 17 beta-estradiol, 17 alpha-ethynylestradiol, and bisphenol A. J Chem Eng Data 51:879-881. https://doi.org/10. 1021/je050318c

Singleton DW, Khan SA (2003) Xenoestrogen exposure and mechanisms of endocrine Disruption. Front Biosci 8:110-118. https://doi.org/10. 2741/1010

Soni H, Padmaja P (2014) Palm shell based activated carbon for removal of bisphenol A: an equilibrium, kinetic and thermodynamic study. J Porous Mater 21:275-284. https://doi.org/10.1007/s10934-0139772-5

Tan BLL, Hawker DW, Müller JF, Leusch FDL, Tremblay LA, Chapman HF (2007) Modelling of the fate of selected endocrine disruptors in a municipal wastewater treatment plant in South East Queensland, Australia. Chemosphere 69:644-654. https://doi.org/10.1016/j. chemosphere.2007.02.057 
Thue PS, Adebayo MA, Lima EC, Sieliechi JM, Machado FM, Dotto GL, Vaghetti JCP, Dias SLP (2016) Preparation, characterization and application of microwave-assisted activated carbons from wood chips for removal of phenol from aqueous solution. J Mol Liq 223:1067-1080. https://doi.org/10.1016/j.molliq.2016.09.032

Tran HN, You SJ, Hosseini-Bandegharaei A, Chao HP (2017) Mistakes and inconsistencies regarding adsorption of contaminants from aqueous solutions: a critical review. Water Res 120:88-116. https://doi.org/10.1016/j.watres.2017.04.014

Tsai W-T, Hsu H-C, Su T-Y, Lin KY, Lin CM (2006a) Adsorption characteristics of bisphenol-A in aqueous solutions onto hydrophobic zeolite. J Colloid Interface Sci 299:513-519. https://doi.org/10. 1016/j.jcis.2006.02.034

Tsai W-T, Lai C-W, Su T-Y (2006b) Adsorption of bisphenol-A from aqueous solution onto minerals and carbon adsorbents. J Hazard Mater 134:169-175. https://doi.org/10.1016/j.jhazmat.2005.10.055

Vos JG, Dybing E, Greim HA, Ladefoged O, Lambré C, Tarazona JV, Brandt I, Vethaak AD (2000) Health effects of endocrine-disrupting chemicals on wildlife, with special reference to the european situation. Crit Rev Toxicol 30:71-133. https://doi.org/10.1080/ 10408440091159176

Wang F, Lu X, Peng W, Deng Y, Zhang T, Hu Y, Li XY (2017) Sorption behavior of bisphenol A and triclosan by graphene: comparison with activated carbon. ACS Omega 2:5378-5384. https://doi.org/10. 1021/acsomega.7b00616

Xu J, Wang L, Zhu Y (2012) Decontamination of bisphenol A from aqueous solution by graphene adsorption. Langmuir 28:84188425. https://doi.org/10.1021/la301476p
Yamamoto T, Yasuhara A, Shiraishi H, Nakasugi O (2001) Bisphenol A in hazardous waste landfill leachates. Chemosphere 42:415-418. https://doi.org/10.1016/S0045-6535(00)00079-5

Zbair M, Ainassaari K, Drif A, Ojala S, Bottlinger M, Pirilä M, Keiski RL, Bensitel M, Brahmi R (2018a) Toward new benchmark adsorbents: preparation and characterization of activated carbon from argan nut shell for bisphenol A removal. Environ Sci Pollut Res 25:1869-1882. https://doi.org/10.1007/s11356-017-0634-6

Zbair M, Ainassaari K, El Assal Z et al (2018b) Steam activation of waste biomass: highly microporous carbon, optimization of bisphenol A, and diuron adsorption by response surface methodology. Environ Sci Pollut Res 25:35657-35671. https://doi.org/10.1007/s11356018-3455-3

Zbair M, Ait Ahsaine H, Anfar Z (2018c) Porous carbon by microwave assisted pyrolysis: an effective and low-cost adsorbent for sulfamethoxazole adsorption and optimization using response surface methodology. J Clean Prod. 202:571-581. https://doi.org/10.1016/ j.jclepro.2018.08.155

Zbair M, Bottlinger M, Ainassaari K, Ojala S, Stein O, Keiski RL, Bensitel M, Brahmi R (2018d) Hydrothermal carbonization of argan nut shell: functional mesoporous carbon with excellent performance in the adsorption of bisphenol A and diuron. Waste Biomass Valoriz 1-20. doi: https://doi.org/10.1007/s12649-018-00554-0

Publisher's note Springer Nature remains neutral with regard to jurisdictional claims in published maps and institutional affiliations. 